\title{
Editorial
}

\section{Tax harmonisation - The US experience}

Paul R. McDaniel, Hill \& Barlow, Boston

Like many US tax advisors, I have been interested in the implications for US business and investor clients of the implementation of a more closely integrated European common market in 1992. And, like many US tax scholars and policymakers, I have been following - and to some extent engaging in - discussions of issues centering around tax harmonization among members of the European Community. The two developments are obviously interrelated.

My impression is that most tax discussions center on the issues of tax base and tax rates. I raise the question, however, whether sufficient attention has been paid to the issues of tax administration, resolution of taxpayer disputes and judicial review as those matters seem likely to come up in the context of (1) a common market and (2) increasingly harmonized tax systems. Or to put the matter another way: After 1992, will there be increased pressures for uniform administrative procedures and interpretation with respect to tax issues in the common market? Are existing practices and procedures under bilateral tax treaties sufficient or will they be too cumbersome in a common market? Will there be a need for a single judicial tribunal to resolve taxpayer disputes throughout the Community and to provide uniform interpretations of increasingly harmonized taxes?

My own experience, of course, is with the very sizable common market in the United States. The operation of an overarching tax system (the Federal taxes) and independent taxing jurisdictions within the market (the individual state taxes) may raise some questions to consider in the European context.

1. Because there is a single Federal government with political control over the entire market, the need for a single tax administration (the IRS) operating throughout the market became necessary once the US adopted global taxes, such as the income tax. To a remarkable degree, the IRS does interpret and apply the Federal tax laws even-handedly and uniformly throughout the country. Of course, 1992 does not envision a 'United States of Europe', but even now VAT revenues collected in the various states support the Brussels political apparatus. If greater power becomes centralized in Brussels, will the need for uniform administration and resolution of taxpayer disputes throughout the market increase?

2. The United States Tax Court operates as a single court throughout the US. Its decisions and its precedents apply to individuals and businesses in every state. The uniformity and consistency of Tax Court decisions is an important element in the overall operation of the US federal taxes. Does thought need to be given to such a judicial entity in a more common and more (tax) harmonized Europe?

3. In the US, each state has independent taxing authority. Each has its own tax administration and judicial system to implement and interpret its tax laws. In general, there is close cooperation between the IRS and the individual state tax administrations. Thus, the existence of a Federal tax system has not operated to preclude the sovereign exercise of each state's taxing authority.

4. Taxpayers operating in more than one state are faced both with the need to comply with differing tax systems and the need to be able to appeal from rules or practices that are antithetical to the common market. Aggrieved taxpayers in such cases can ultimately take their cases to the US Supreme Court. Will a similar judicial body be needed as the implications of 1992 unfold in the European Community?

I discuss the US practices, not because they are transferrable as such to the European Community, but because the questions to which they respond may well be similar to those that Europe will face after 1992. In this regard, I found it helpful to review again the 1980 study by Professor Gustaf Lindencrona and Professor Nils Mattsson, Arbitration in Taxation (P.A. Norsted \& Soners: Stockholm, 1981). Of particular interest are their discussions of the need for an 'Arbitration Institute' to resolve taxpayer disputes when more than one country is involved and for an 'International Tax Court'. If readers believe the questions raised above do seem relevant in the context of the emerging more common and more tax-harmonized market, the Lindencrona/Mattsson study is a good starting point for analysis. 